\title{
Amílcar Cabral and Amartya Sen
}

\section{Freedom, Resistance and Radical Realism}

\author{
Lawrence Hamilton
}

Abstract: This article compares the ideas of Amílcar Cabral and Amartya Sen on capability, freedom, resistance and political change, thereby revealing the importance of radical realism in political thought and development studies. Sen's path-breaking work has been transformative for multiple disciplines, not least development. Yet, reading Sen alongside the ideas of one of Africa's most successful anti-colonial political leaders is revelatory: it provides the basis for the argument that radical realism is most valuable if it is action-guiding, comparative and about context-specific change. This involves a distinction between realistic political theory and realism in political thought where only the latter demands utopian thinking. What follows from this regarding democracy, impartiality and justice? In answering this with reference to some social movements, the article then defends the political potential of conflict, partisan positions, resistance and political change directed towards overcoming domination.

Keywords: Amartya Sen, Amílcar Cabral, capability, freedom, political change, political theory, radical realism, resistance

Resistance is the following: to destroy one thing for the sake of constructing another. That is resistance. What is it that we want to destroy in our land? The colonial domination of the tugas [Portuguese colonialists]. Only that? No. At the same time, we don't want any other type of colonial domination in our land - any other type of foreign domination whatsoever. ... We want ... to destroy everything that would be an obstacle to the progress ... 
and liberty of our people. At the end of the day, we want the following: concrete and equal possibilities for any child of our land, man or woman, to advance as a human being, to give all of his or her capacity, to develop his or her body and spirit, in order to be a man or a woman at the height of his or her actual ability.

- Amílcar Cabral (1969 [2016]: 76-77) ${ }^{1}$

It is arguable that what is missing in all this [utilitarian and Rawlsian] framework is some notion of 'basic capabilities': a person being able to do certain basic things. The ability to move about is the relevant one here, but one can consider others, e.g., the ability to meet one's nutritional requirements, the wherewithal to be clothed and sheltered, the power to participate in the social life of the community.

- Amartya Sen (1980: 218)

Much mainstream political theory and development studies has tended to be too parochial, abstract and cautious to be of practical help in orienting agents in politics, to help us judge what is a good or a bad idea and to decide how best to get from a particular here and now to a more prized future. By comparing the ideas of Amílcar Cabral and Amartya Sen, that is, by comparing all-too-often ignored arguments drawn from resistance to colonisation in Africa with a series of famous moves made against hegemonic political and economic theories, this article reveals and defends a more valuable mode of political thinking for development. It is more valuable, as it is action-guiding and thus more practically relevant. This is because it is more realist, comparative and focussed on how to bring about change. Sen's path-breaking work has been transformative for multiple disciplines, not least development studies. Yet, reading Sen's ideas alongside Cabral's, as I do here, reveals important omissions and assumptions that undermine the intended realism of Sen's thought and thus its practicability for development studies. This comparison is also important as it draws on figures, ideas and problems that come from outside the geographical confines of Europe. It therefore broadens the discursive frame for thinking politically as espoused by post-colonial thought and decolonial activism, and it gives us new and better insights into how political theory and development studies can become more realist and utopian. It simultaneously grounds political thinking in specific, local 
political challenges (particularly when change is necessary to overcome domination) and enables theorists from the Global North and Global South to see beyond their own horizons of what is possible and (seemingly) impossible (Hountondji 1997). The radical realism that emerges from this comparison would demonstrate bolder ambition as regards political change, resistance to domination and fighting for freedom.

Cabral and Sen give us exemplary access into this mode of thinking: their work is directed towards improving the lives and possibilities of those whom Frantz Fanon called 'the wretched of the earth', the impoverished millions ravaged by famine, colonial and post-colonial brutalities and civil discord (Fanon 1961; see also Cabral 1979; and Sen 1973, 1981, 1999). Cabral undertook this at the helm of arguably Africa's most successful military anti-colonial revolutionary struggle, the Guinea and Cabo Verde liberation movement, Partido Africano da Independência da Guiné e Cabo Verde (PAIGC) (Borges 2019). Sen too has become a global icon both as a highly successful economist and philosopher and in the development of new techniques of analysis and measurement that have been adopted by, amongst others, the United Nations (UN). They are also both students and scholars of a period of great change in Africa and South Asia. ${ }^{2}$ One of their main intellectual and political influences was what one might call the 'high-tide' of Marxism as an alternative to capitalism and as a spur for revolutionary (and other forms of) change: Cabral in Lisbon and across Africa; Sen in Delhi, London and Oxford. And despite this then prevalent, firm (and sometimes dogmatic) theoretical framework, neither allowed it to be the only prism through which they viewed and understood 'reality', as discussed in greater detail below. Crucially and relatedly, they both place capability and freedom at the heart of everything they espouse, not some etiolated liberal view of freedom as non-interference, but a richer, more substantive account of real freedom as effective power (Hamilton 2013, 2014a, 2014b, 2019). This is the substance of the first of this article's epigraphs, which is the goal towards which Cabral's resistance to colonial domination is directed. And, as suggested by the article's second epigraph, Cabral's ethics mirror Sen's.

Although Cabral and Sen begin from similar ethical positions and concerns with development more generally, the extent to which they 
remain sensitive to context and diagnosis explains a subsequent divergence, or so I shall argue. Cabral remains resolutely realist (actionguiding) in his theoretical moves: he emphasises the importance of local, practical knowledge about and for resistance in a specific context. Sen, on the other hand, despite an emphasis on theoretical incompleteness and a 'comparative' critique of John Rawls on justice, cleaves to a set of universal theories or axiomatic positions that can he assumes - guide action in every context. He remains wedded to universal accounts of reason and impartiality based on his arguments for capability expansion via social choice, public reason and rational deliberation. In short, Cabral provides a telling example of how resistance is central to overcoming injustice (in his case, that of colonial rule) and how to forge change on the ground for development; while Sen submits a much more consensual view of politics in which resistance is conspicuous by its absence, despite arguably constituting the core of a new way of rethinking development via capabilities analysis and goals driven by, amongst other things, 'public action'. ${ }^{3}$

The main point of this comparison is that the differences in Cabral's and Sen's contexts, goals, language and thought are shown to be as important as the similarities. This is no surprise. They may posit a similar account of the development of human capacities and powers, but, for example, they have markedly different views on political change.

Some may think it awkward or unfair to compare the ideas of a university academic with those of a revolutionary activist. Cabral was fundamentally action-oriented and steeped in practical revolutionary work, whereas Sen is unequivocally a theorist. It may be unfair, but it is nonetheless illuminating, partly because it is disruptive of how we think about these silos: real action versus theory in thinking about politics. In any case, Cabral was no ordinary revolutionary engaged in armed resistance to colonial rule. Although his primary objective was to mobilise his compatriots for the radical realisation of his ideas, he was also an accomplished theorist and poet. And Sen is no ordinary theorist: extraordinarily huge volumes of theoretical contributions to many fields in economics, philosophy and beyond; and he was a man of action - he has been actively involved in a whole array of practical achievements, with the World Bank and the UN at a global level, in Europe, the United States and India more specifically, changing how many practise development. 
The comparison may be jarring for some, but that is, in part, the point: to disrupt the distinctions that provide succor to theorists of politics and development, namely, that theory cannot (and thus should not) be forced out of context, history, partial political positions and (potential) conflict. To assume that it can only be legitimate and persuasive if it adopts universal axiomatic positions and arguments based on reason, impartiality and the like is, I shall argue, to misunderstand one of the points of political theory: to use context, history, language, theoretical abstraction, moral suasion, amongst other things, to convince your fellow citizens to think and act in one way as opposed to another, that is, to guide and inform action in a particular context and time - or, in other words, to bring about change. Bringing these differences out by means of a comparison between Cabral and Sen on development and capability (Section 2), freedom (Section 3), resistance (Section 4) and political change (Section 5) helps to identify a distinction between realistic political theory and realism in political theory, where the latter cannot proceed without utopianism. Especially when significant change is necessary, politics is not the art of the possible, but the art of the impossible, and this is as true of change in politics in general as it is of change in development.

\section{Realism in Political Theory}

The revival of realism in political theory is two decades old now, inspired mainly by the work of Bernard Williams (2005) and Raymond Geuss (2001, 2008a). Though there is no single, fixed position as regards what it is to be a realist political theorist, various positions are coalescing around four main characteristics (Rossi and Sleat 2014). First, a realist political theory must start from and be concerned in the first instance not with how people ought ideally (or 'rationally') to act, desire, value and so on, but rather with the way the social, economic and political institutions actually operate in some society at a given time and what really does move humans to act in given circumstances. Second, a realist political theory recognises that politics is in the first instance about action and the contexts of action, often involving conflict. Third, politics is historically located. Politics has to do with the interaction of humans 
in institutional contexts that change over time, and the study of politics must reflect this fact. In other words, political theory and development cannot escape history and context. Although this is no objection to generalising, if one wants understanding or any guidance to action one has to take the specific cultural and historical circumstances into consideration. Fourth, given that the circumstances are always changing (that is, genuinely different and unexpected), politics is not about applying or mastering certain theories. It is more like a craft, art or skill: there is no axiomatic, universal theory that can guide action in every context and circumstance (Geuss 2008a, 2016; Runciman 2012).

This is quite distinct from 'realism' in international relations, which is entirely focussed on power and interests in politics. By contrast, while realism in political theory keeps power and interests central to politics, it views these in terms of power relations, mutable interests, contextual values and utopian imaginative forays that enable us to 'dare to invent the future' (Sankara 2007: 232). In particular, what has been called 'radical realism in political theory' is focussed primarily on enabling one to question and resist the status quo, that is, to be subversively and transformatively critical of it (Geuss 2008b; Prinz 2016). This requires a diagnostic, critical approach to the existing normative and institutional order of the context in question, which depends upon local, practical knowledge about and for the context and acceptance that, by dint of its necessarily historical and contextual nature, political theory will normally be partisan, embroiled in power relations and, potentially, conflictual.

That radical realism in political theory embraces partisan conflict and utopian transformation is important for understanding Cabral. He often mentions the importance of being realistic. He argues that 'in politics one has to be realistic' (Cabral 1972: 7). But to impute from this that he is a 'realistic' thinker is a mistake, for to be realistic is not the same as being a realist in political theory. Someone who is 'realistic' accepts the existing framework for defining what is possible and impossible and, as Geuss argues, 'tries to cut his desires to fit the cloth that his particular society has made available'. What is possible and impossible is context-dependent: it is both highly variable and a social construct in the sense that to some extent it always reflects the given distribution of powers and interests, which are 
generally articulated through given laws. A realist who understands this 'will refuse to take this distinction as it is socially defined at any given moment to be the final and unquestioned framework for thought or action' (Geuss 2016: 43). In other words, in contrast to a realistic political agent, a realist will strive for the impossible beyond the given laws of her society; she will, without contradiction, be utopian in thought or action. Or, with a little poetic license, the 1968 slogan 'be realistic - demand the impossible' can become 'be a realist - demand the impossible'. As will become apparent as this article unfolds, I think we can safely say that Cabral sells himself short: as a revolutionary political agent, he is striving and resisting in a realist, not realistic fashion.

The same, however, cannot be said for Sen. This is the case notwithstanding Sen's important conceptual critique of capitalism's theoretical foundations, and the fact that he himself submits his work as a realistic approach to social and economic theory that is useful for resolving a series of practical deprivations related to poverty, famine, inequality, development, freedom, democracy and justice (Sen 1973, 1981, 1987, 1999). Now, as compared to the work of Rawls and his followers, Sen may well seem so. For, unlike this highly dominant strain of theory, characterised as it still is by abstract theorising around the nature of a perfectly just society on the basis of moral philosophical foundations, ${ }^{4}$ Sen's alternative 'comparative', 'realisations-based' account of justice, with its focus on making judgements about justice and injustice without full agreement on an ideally just society, may easily seem like an instance of realism in political theory (Raekstad 2015; Sen 2009). But this conclusion is over-hasty. Sen is not a realist in the sense being espoused here for two main reasons. First, at least in The Idea of Justice, his magnum opus, Sen reduces the myriad of values and concerns in politics to one particular social ideal, the ideal of justice, about which I will discuss more below. Second, despite his various conceptual advances, especially his compelling 'concern for capabilities', Sen is silent on how best to assess and criticise existing power relations and the associated forms of domination that may obtain in extant economic and political institutions. More specifically, his concern for capabilities does not provide a convincing basis for critique and thus resistance of the formation of practices and preferences. This is the case because 
it is not intended to resist the underpinning of extant political and economic orders; it is intended as a politically impartial set of conceptual and evaluative tools to replace utility and welfare. In other words, it is not proposed as a means of enabling political change, if this is understood as requiring and involving significant and meaningful change to the institutions and practices upon which liberal capitalist societies rest. To bring these points out, I will now turn to comparing Cabral and Sen on capability, development, freedom, resistance and change.

\section{Development and Capability}

The link between development and capability is as apparent in the work of Cabral as it is, most famously, in the work of Sen. Shorn, for the moment, of its conceptual architecture, capability, according to Sen, is the individual ability, determined by developmental circumstance, to do this or be that - that is, the freedom and power necessary for individuals to be well nourished, to be able to read, write and communicate, to take part in literary and scientific pursuits, and so on. Thus, as he puts it, the 'process of economic development can be seen as a process of expanding the capabilities of people' (Sen 1983: 755).

In a similar vein, Cabral makes constant reference to developing the powers and capacities of Africans under and in order to overcome Portuguese colonial domination in Guinea and Cabo Verde: 'That's exactly the objective of our party: to develop all of our capacity ... to eliminate all that impedes us from having this capacity ... to advance like other peoples of the world, for progress, for a life of dignity' (Cabral (1969 [2016]): 78, 148; 1969: 14). Although I leave his analysis of colonialism and imperialism to one side here, this association is clear therein too, in particular the association between these forms of domination and the lack of freedom to do what he deems a natural part of human existence: to develop one's own capacities and powers. As he puts it in his famous 'Weapon of Theory' speech: 'The principal characteristic of imperial domination, whatever its form, is the usurpation by violence of the freedom of the process of development of the dominated ... National liberation is the [return] of every people to 
[its] own history; and ... the aim of national liberation ... is to free the process of development' (Cabral 1979: 130). In other words, besides the barbarism and violence inherent in colonial and imperial domination, its main effect is to stifle, destroy or block the 'process of development'.

These similarities in Cabral and Sen are hardly surprising, given the centrality of Karl Marx's ideas in the work of both thinkers. Sen is known for happily cherry-picking from the history of political thought, but Marx looms larger than most, all the way from lengthy discussions in On Economic Inequality to repeated references in the The Idea of Justice. The more obvious marxisant phraseology of some of Cabral's writings similarly leaves us in no doubt. However, neither thinker allows the theoretical architecture of Marx (or at least 'Marxisms') to constrain them. This is well documented in Sen. As regards Cabral, the jury is still out, but those who knew him well say very similar things. Take, for example, Basil Davidson's comment - 'If one had to define a single influential aspect of Cabral's approach, perhaps it would be his insistence on the study of reality' (Cabral 1979: xi) - or Vladimir Shubin's admiration for Cabral's unstinting realism: 'I recall how, at our last meeting in Moscow in December 1972, soon after he received PhD Honoris Causa from the Russian Academy of Sciences, he said "when you go to Africa you should take off your Marxist jacket and put on a khaki shirt"” (2017: 227).

Cabral emphasises 'progress', reclaiming one's own 'history' and 'development' (1969: 14). As is discussed below when I analyse his account of cultural resistance, for Cabral there is no contradiction in this as he is not suggesting that the process of reclaiming one's own history requires the return to some primordial, pre-colonial history. Rather, it involves the political and economic freedom to have the power to make one's own history again as a people. Thus, he argues that the pre-requisite for progress is 'the elimination of ... economic domination' and the elimination of all exploitation, including traditional cultural forms. As he puts it: 'We have been exploited by the traditional chiefs, by other sections of our society, and by the colonial power' (Cabral 1972: 17).

Sen developed his concern for capabilities out of overlapping work on poverty and famines, especially the Bengal famine under colonial rule, social choice theory and dissatisfaction with the 
predominant moral and political philosophies in the developed West: utilitarianism and neo-Kantianism. In place of 'utility' on the one hand and 'resources' or 'primary goods' on the other, Sen proposes two inter-linked concepts for the evaluation of well-being and the design of policy: functionings and capabilities. These are what people are effectively able to do and to be. Functionings are valued states of beings or doings: what a person 'manages to do or be in leading a life'. These include a wide range of 'states' from elementary ones, such as being adequately nourished, to complex activities, such as being able to take part in the life of the community (Sen 1973: 31; 1999: 75). The capability of a person 'reflects the alternative combinations of functionings the person can achieve, and from which he or she can choose one collection' (Sen 1993); or, in other words, it refers to whether a person has effective access to valued functionings. These conceptual innovations refocus economic and political theory and development studies onto what goods do for humans, that is, how they enable (or disable) humans to lead the lives they would reasonably choose to lead (Hamilton 2019).

The crux of my argument here is that Sen's capability approach has a similar ethical and development base to the one expressed in Cabral's revolutionary writings. They are similar too in the way they marshal their ideas. Famously, Sen goes on to conceive of many development issues in terms of capability deprivation, providing him with a single ready tool with which to conceptualise and evaluate issues that bedevil developing and developed countries - health, literacy, poverty, inequality, gender discrimination, etc. Before him, both as an agronomist and in his subsequent revolutionary writings, Cabral focussed on how to fight his homeland's very poor and distorted levels of literacy, health, gender inequality and so on. For example, until 1959, under the 'golden age' of Portuguese colonialism, as he ironically puts it, 'in Cabo Verde, more people have died from starvation than the actual present population of the country' (Cabral 1973: 25). In various speeches to the UN he goes on to list the severe deprivations of 'his' people, and in a famous one in 1972 he marshals an array of statistics to show how the PAIGC has improved the wellbeing of those living under the liberated areas of Guinea (Cabral 1973: 25). 


\section{Freedom as Effective Power}

Moreover, both Sen and Cabral link 'capability' or 'capacity' to freedom as effective power. In other words, they do not reduce freedom to one of three main views: the idea that freedom is a matter of non-interference ('negative' freedom); autonomy ('positive' freedom); or living actively in a free state ('republican' or 'neoRoman' freedom). Rather, they conceive of freedom in more ample, concrete and substantive terms by linking it to power. In line with Marx, they think of freedom as being about the practical combination of a person's ability to determine what they will do and the power to do it or bring it about (Hamilton 2014b).

For Sen, the capability to function comprises the various combinations of functionings that reflect the person's freedom to lead one type of life or another; that is, it reflects the person's ability (dependent in part on her living conditions) to choose from possible lives. ${ }^{5}$ The actual functionings - or achieved beings and doings - of a person therefore make up part of the capability set but are not equal to it. There are four more conceptual categories, which are all valuable for an individual's quality of life, but are not functionings per se: well-being achievement, well-being freedom, agency achievement and agency freedom. The details need not detain us here, except to highlight the fact that Sen mounts a strong argument for the intrinsic and instrumental value of freedom via a focus on choice: 'Doing $x$ and choosing to do $x$ are, in general, not equivalent' (Sen 1985: 202). Thus, for Sen, substantive freedom, although not equivalent to capability or functioning achievement, nevertheless depends on a person's power to bring about the capability set or 'the objects of her reasoned choice'. Functionings and capabilities enable us properly to conceive of and measure the quality of life. This is an understanding of freedom as effective choice or the power to make and scrutinise the whole range of choices that constitute a human life. That humans have these choices and the power to bring them about and to provide and assess the reasons for having them is central to Sen's view of freedom as effective power. He expresses the link between choice, capability, freedom and effective power unambiguously: 'The question whether a person can bring about the objects of her reasoned choice is crucial to the idea of freedom being pursued here, of which the notion of capability is a part. Freedom [can 
be achieved by means of] direct control ... or 'indirect power' .... the issue of effective power' (Sen 2009: 301-302).

Similarly, Cabral expressly links the development of capacities to freedom and thus freedom to effective power. In Our People are Our Mountains, he argues with some force that 'we like peace, but peace means nothing without freedom ... We are freedom fighters our aim is the independence of our country and the total freedom and progress of our people' (1972: 3-9). Freedom, he claims, is the liberation of all of his countries' productive forces, which requires the liquidation of all forms of colonial domination, the development of social, economic and political institutions that enable equality, justice and freedom, and the taking back of 'our destiny and our history' (1972: 8). The link is clear in his discussion of the negative effects of colonialism. Once colonialism was well rooted, Cabral argues, it had a stagnating effect on colonised peoples and their histories: 'Our history, our freedom, and the freedom of our productive forces were taken and stifled by the colonialists' (Cabral 1969 [2016]: 144). Military successes are decisive, Cabral argues, but 'the most important success for us is the capacity to create a new life' helped by growing numbers of agronomists, doctors, engineers, teachers, lawyers, and so on (1972: 7).

True to this, once the PAIGC had control of half of Guinea in 1966 , not only did they quickly improve the quality of life of what had been an extremely impoverished and nearly completely illiterate population, but they also put in place village democracy, including popular assemblies and judicial institutions. I cannot go into these in detail here, though there is one crucial thing to note about these 'liberated zones'. In them, the PAIGC quickly moved to help improve the quality of life of their inhabitants via securing valued opportunities and freedoms, in particular access to agricultural products, but also education in general and militant education in particular, that is, a combination of technical skills and forms of individual and collective consciousness and training aimed at the development of the self and the liberated African citizen (Borges 2019). Anti-colonial and decolonial principles and political freedom were, needless to say, central to this project but so too were general means of empowering individuals to lead lives of free choice and power as regards their individual choices (as militants, farmers, mothers, etc.). 


\section{Resistance}

Given the circumstances about which Cabral wrote and reflected eventually a violent and successful military struggle for liberation it is unsurprising that resistance was central to his ideas. Cabral argues that resistance to achieve political freedom is necessary for development and that it demands courage. He discusses four kinds of resistance: political resistance, economic resistance, cultural resistance and armed resistance.

Each form of resistance, he notes, is a response to a type of Portuguese colonial oppression (Cabral 1969 [2016]). In general, given the fascist regime in Portugal, 'the slightest attempt on our part to gain our rights was answered by severe and often bloody repression by the Portuguese' (Cabral 1972: 6). I shall spare you the details of this violent repression of the entire population, which included the use of napalm and white phosphorous, but one event is a defining moment in the struggle. On 19 September 1956, the PAIGC was set up and first attempted to resist by peaceful means. On 3 August 1959, during a workers' strike in Bissau, fifty African workers were murdered and more than one hundred wounded in twenty minutes. It became known as the 'massacre of Pindjiguiti Quay'. The PAIGC decided then to go underground, move to the countryside and prepare themselves for armed struggle (Cabral 1972). As Cabral says clearly: 'We took up this struggle only in answer to the violent oppression of our people by the Portuguese colonialists' (1972: 11). This turn to the countryside was also inspired by how the demographics of Guinea reinforced what Cabral had learnt from the strategies of Ho Chi Minh and Mao Tse Tung: a very small urban working class, whose efforts to resist were repeatedly crushed by a ruthless urban-based colonial police, and the rest of the country characterised by impoverished, disaffected peasant farmers. A move to the 'rural masses' also enabled the PAIGC to train and elicit support from the greatest possible number of Guineans (Cabral 1969; 1979).

Cabral specifies a series of essential objects of political resistance. It is vital to 'unite people' by focussing on improving their lives (1969 [2016]), always recalling that, as he puts it, 'we consider unity to be a means, not an end' (1969: 65). It is crucial to win local and international allies $(1969,1972)$. And it is imperative to 
'isolate the enemy from his own people', and all his allies (1969 [2016]: 84).

Regarding economic resistance, Cabral argues as follows. 'African revolution means the transformation of our present life in the direction of progress. The prerequisite for this is the elimination of foreign economic domination, on which every other domination is dependent' (1969: 14). In a whole series of fascinating historical accounts of how Portuguese colonial power manifested itself, he sums up the Portuguese strategy in Africa as follows: 'Firstly, growth of the white population; secondly, limitation of the black population' (1972: 29). An abhorrent racist political agenda drives a nonsensical and destructive economic agenda. To resist this, Cabral claims, is to do the opposite: to help develop all Africans to their full potential by removing - by force, if necessary - the barriers imposed by this Portuguese colonial agenda. ${ }^{6}$

Cabral links resistance to cultural domination to development and capability: 'A people who free themselves from foreign domination will be free culturally only if, without complexes and without underestimating the importance of positive accretions from the oppressor and other cultures, they return to the upward paths of their own culture ... Thus ... national liberation is necessarily an act of culture' (1973: 42-43). He is, though, careful not to essentialise culture. Later, he even argues that, dependent on context, some parts of a culture under national liberation - the vertical hierarchy of the Fula in Guinea, for example - are easily exploited by the colonisers. Chiefs, and their associates, are co-opted, lose their link to their culture and then, on liberation, try to return to some original, hierarchical structure. This is because they have been alienated from their own culture. Cabral thinks this is a dangerous form of 're-Africanisation' that should be avoided at all costs. ${ }^{7}$ In general, Cabral warns against the tendency to hark back romantically to pre-colonial African culture, even arguing for the need to learn from some colonial methods, such as science and education, aligning with his constant stress on progress.

For Cabral, the objectives of armed resistance were manifold: destroy the enemy's forces, which requires killing all tugas who bear arms against the people; minimum loss of comrades; 'remove the colonialist from our land'; ensure 'the people' remain on side as they need to rise up too (e.g. in the Algerian War of Independence); 
confront the enemy from all sides (in Guinea, Cabo Verde, Mozambique, Angola and so on); and, finally, get the enemy to 'sit down and say that we're right, that we can take our land' (1969 [2016]: 150-155).

And this is where Cabral and Sen diverge dramatically. Any reference to resistance is conspicuous by its absence in the work of Sen, with one or two exceptions in his most recent co-authored work; in a few interviews on India, where he says, for example, that 'caste triggered resistance in Kerala, and that resulted in genuine development'; and in a couple of responses to criticisms of his theoretical work (Drèze and Sen 2013; Sen 2014, 2015). For example, when James Tully notes that Sen 'leaves intact the hegemony of a liberal form of democracy that prioritizes political and civil rights over social and economic rights' (2013: 220), Sen protests by pointing to his argument in The Idea of Justice that 'keeping the space reserved only for liberty and first-generation rights ... attempts to draw a line in the sand that is hard to sustain' (2009: 385). Yet, this is a hardly a call to resistance. It is made as part of a subtle, if important, point about the nature of human rights. If it is a call to action, it is one that is not intended to shake up the existing hegemonic order, but rather to work within it on the assumption that it is generally sound.

\section{Resistance, Realism and Political Change}

This difference around the centrality of resistance in the writings of Cabral and Sen points to a deeper divergence. This divergence is most prevalent in three major themes, all of which revolve around the question of how best to bring about political change for development: justice, taking sides and dealing with conflict; focus on the local; and impartial global institutions. While what I have to say positively as regards what Cabral argues is in the context of a military liberation struggle, these modes of thinking about politics apply just as well to the question of how best to bring about policy and institutional change for development. While Cabral emphasises partiality, local knowledge and struggle, Sen espouses impartiality, global ideals and goals, and supposedly global sites of change. 


\section{Cabral's Realism}

The PAIGC were very successful combatants: by 1966, that is, within only three years of the start of the liberation war, 50 per cent of the colony and half of its population were under the control of the PAIGC; by 1971, the PAIGC controlled more than two-thirds of Guinea; in 1971 alone, they managed to kill over 500 of the Portuguese colonial forces, detaining many more. They also carried out several successful strikes on all major urban centres (Cabral 1972). The only reason Portugal could keep up the fight for as long as it did was because of the significant military support it received from NATO. Otherwise, the war would have been won by 1971 (Cabral 1972, 1973). When asked about its successes and how Cabral's experience of armed struggle can shed light on the theory of armed struggle in general, he stated clearly that, while the experience of armed struggle by the PAIGC may be useful to others, 'we think that our experience is our experience ... the basic theory of armed struggle has to come from the reality of the fight; practice comes first, theory later'. Writ large, this is the basis of his realism: 'Study the real, concrete conditions that face you' (1972: 20-21).

In sum, Cabral's realism can be articulated in four major insights. First, in attempting to overcome domination there is no point in trying to espouse an impartial, universal perspective. Partial positions that take sides and delineate a clear enemy are also the best means to win external allies with similar concerns or enemies (Cabral 1969 [2016]). Second, seek local, comprehensive knowledge of your enemy: 'We should be cognizant of what we want to destroy and construct in our land ... Who are we, who is our enemy?' (1969 [2016]: 78). Third, know your circumstances in two senses: whence you struggle; whence your fighters. Mobilise not on the basis of supposedly universal ideologies or theories of class, but 'on the basis of the daily realities of suffering and exploitation' in your context (1972: 22).

Fourth, Cabral has little faith in global institutions with no powers of enforcement, such as the UN. As he said in in a speech in late March 1961, at the Third All-African People's Conference held in Cairo, 'despite the resolutions favourable to our struggle, that organization has shown itself incapable of resolving disputes between colonized peoples and colonial powers' (1969: 7-19). He made three famous speeches before the UN, only to be frustrated. 
He once said that an institution over which the UN ought to have some control, NATO, has done nothing more than aid Portugal with arms to repress all resistance, which were used to drop napalm, to carpet bomb and so on (Cabral 1973). Yet, he is not so obsessed with the local that he forgets the global, moral force of the UN. He knows he needs this audience on side. His realism, though, is never far off, even when addressing this audience. As he puts it: 'For as we Africans say, "Only in stories is it possible to cross the river on the shoulders of the crocodile's friend"' (1973: 24). In other words, he cautions against too much blind faith in the UN's will or capacity to bring about change.

\section{Justice and Judgement}

The distinction I have drawn between realistic and realist is particularly apposite as regards the reduction of politics to justice. This is clearly evident in the work of Sen. Although Sen's argument for a partial and comparative view of justice in dealing with injustices provides an important corrective to the mainstream of normative political theory regarding how overcoming injustices is intrinsic to development, ultimately it falls back onto a series of universal assumptions that are not intended to reach beyond the existing basic order of our polities: 'open impartiality', 'plural reasons' and democratic deliberation guided by 'public reason' (2006; 2009). Sen is concerned with behaviour and social choice mechanisms to resolve distributional questions of justice; he is not concerned with critiquing the basic institutional structure of modern polities. While Sen may be more realistic than, say, Rawls, his thought is not intended to guide political action that resists by thinking beyond the existing basic structure and laws of 'ordered' societies; rather, his focus is on dealing with specific instances of injustice, the need for reasoned agreement, and behavioural transgressions (as opposed to institutional shortcomings) (Sen 2009).

Even Sen's very focus on justice is telling. The tendency in development discourse, progressive parlance and analytical political philosophy to reduce politics to one particular social ideal - distributive justice - rests on an unhelpful slippage. If you think that 'justice' is 'all the human excellences together', what Aristotle called 'universal justice' (1980: 1129b-30), then of course it comes as no surprise that all politics is about justice. It is no surprise because it 
is a tautology. The problem arises when a theorist moves from the tautology that 'justice' is about what is socially desirable to something that is by no means a tautology, 'namely to the claim that all politics is appropriately construed as the equitable or proportional distribution of pre-existing goods and benefits' (Geuss 2014: 158).

In particular, there are four problems with this slippage. First, as many theorists and activists have expressed (especially during real struggles for liberation from domination under colonialism, imperialism, apartheid and patriarchy), not all politics is about justice. Politics is also at least about freedom, security, the coordination of action, legitimacy, the exercise of influence, the regulation of power relations, the overcoming of domination, development, the control of the use of force and so on (Geuss 2001, 2014; Shapiro 2016).

Second, this unique focus on distributive justice presumes that justice will have something to do with rules (and principles) and conformity to such existing rules or with conformity to a better set of ideal rules. In other words, there is also conceptual slippage back to another two senses of 'just': (1) 'just' designates that which accords with existing legal codes; and (2) 'just' accords with what we - which 'we'? - think ought to be the enforced legal code (Geuss 2014). ${ }^{8}$

Third, the distributive view of justice always associates justice with the distribution of goods that are considered to exist antecedently. And, as Marx pointed out, the goods in question are taken at face value as objects that come into existence in ways that are irrelevant to discuss (Marx 1867). Marx thought it more important for political theory to scrutinise the activities through which such goods were produced and the social relations that structured these productive processes. For Marx (1939-1941), these were the most important features of any society, and justice in the sense of rules of distribution, in the sense of conformity to a legal code or some more desirable scheme of distribution, was secondary. Although Sen is crucially interested in how goods are converted (differentially) by humans into improving their powers and capacities as humans, that is, his focus is on whole human lives not merely the distribution of pre-existing goods, he does not escape this criticism fully. This is the case because his capability-inspired ethics (and associated view of economics) does not translate into an analysis of how goods are 
produced and what effect they may have on our preferences; that is, he spends insufficient time on the nested, contextual and political nature of these goods and desires.

Fourth, the predominant claims about justice refer to equal (or proportional) distribution of goods fundamental to our social order or to an ideally 'good' social order: but, 'what is so special about “our” notions of social order?' (Geuss 2014: 160). Despite Sen's disavowal of requiring a conception of an ideally good social order', he is also susceptible to this critique, as there is nothing in his account of justice that is aimed at questioning the basic foundations of our existing social orders (Sen 2009). Contrast this to Cabral's views on the creation of a 'new life' and the practical application of it in the 'liberated zones', as discussed above.

Conceiving of justice as central to politics may be the result of a number of understandable phenomena. First, justice has historically been linked with the concepts of rationality and reasonableness, which in their extreme form (Plato, Kant, Rawls) leave little room for actual political judgement and the conflict that might arise out of it (Hampshire 2000); but it is hard to see how justice, even in its most subtle form, as in Sen, takes real judgement and dispute into account. This is the case because even Sen's (2009) outcomesoriented deliberation falls back on a conception of public reason that requires all claims to pass before the reasoned assessment of the public via the notion of an impartial spectator who would assess them from near and far (to avoid parochialism and to include all the necessary, global information in the assessment).

The 'open impartiality' Sen defends is taken explicitly from Adam Smith's (1790) idea of the 'impartial spectator' as a means of locating the process of assessing injustices in actual sentiments near and far, that is, preferences, interests and values drawn from parochial contexts and ones located far away. This, submits Sen, gives his account of justice a more global character. However, there is a drawback to this move. In contrast to Rawls' idea of the 'original position', for example, the idea of the 'impartial spectator' does not depend on asking people to affirm what they would have chosen in principle but what they have chosen and why they have chosen it: the centrally important role of existing 'plural reasons' and how they are played out in the various deliberative democratic fora which Sen has in mind. In drawing on actual reasons as opposed 
to hypothetical ones, Sen has to show that there is in fact a degree of consensus in support of the principles of justice sought in these cases. However, even his own examples - tackling slavery and the subjugation of women - are not very encouraging, especially if viewed from a global perspective: slavery has been practised all over the world for millennia (Shapiro 2011), and it is far from true that the subjugation of women has been eradicated, even in rich democracies. Cabral (1969 [2016]) requires no equivalent degree of consensus or impartiality; in fact, he insists on the importance of circumstance, action and partial resistance as necessary to overcome instances of domination.

In realist spirit, it is also important to ask how Sen's prescriptions as regards justice could be actualised or institutionalised. At times, as if prescient as regards the above critique, both Smith (1790) and Sen (2009) suggest that the idea of an impartial spectator is another form of heuristic, as this 'position' is not that of the actual views of those near and far but in fact the capacity for individuals to stand back and judge theirs and others' values, judgements and claims based on the 'as if' assumption of adopting the position of the impartial spectator. But, is this not asking too much of the capacity for impartiality amongst citizens as they struggle to have their needs and interests heard and met? Also, why are only needs and interests that pass the full test of public reason admissible? As I suggest below, there may exist partisan, legitimate needs that 'the public' in general would not view as reasonable or rational.

Judgement is crucial, too, to the second phenomenon: given our horror at the uncertainty and indeterminacy of human life, and our anxiety at having to exercise judgement to decide in each case how to act in the world, justice provides us with a two-pronged exit out of this state of horror. It enables us to cling to theories we have once committed ourselves to, even if they have revealed themselves as flawed; and it upholds the objectivity and determinacy we seek. To start from 'justice' gives us the illusion that all the indeterminacies of our forms of valuation can be reduced to one objective, rational ideal. We therefore do not need to exercise judgement, or so the illusion is created (Geuss 2014).

Even if there are understandable motivations for us to cling to justice as central to politics, they are seriously flawed as attempts to understand politics and to judge how best to act in the world of 
politics. What is needed is the courage to jettison some of the main underpinnings of the received views on justice and begin from real politics and real, contextual demands of development. This requires political theorists and development practitioners to (1) accept that justice might always involve irreducible conflict (Hampshire 2000); (2) see that the evaluation of how behaviour and institutions form needs, interests and rights lies at the heart of justice; and (3) assess existing power relations in terms of whether they generate domination. In order to right this ship of justice, theorists and practitioners need to take more seriously two related and under-emphasised components of justice. First, judgement, power relations and overcoming domination are central to achieving practical justice. Second, it is necessary to combine an account of freedom with the identification, satisfaction and evaluation of needs and to show how a politics of needs is not first and foremost aimed at resolving conflict but is rather, at least in part, about justifying partisan institutions of representation that may help institutionalise and control (class and other) conflicts. This is freedom as effective power through representation, and it is a central component of development. ${ }^{9}$

\section{Power, Domination and Conflict}

Realist thinkers tend to view the political world in starker terms than we find in Sen. Freedom as effective power in Niccolò Machiavelli, Marx, Cabral, Fanon or Nelson Mandela, to name but a few, is the result not of impartiality of deliberation based on public reason but on partial resistance to domination, which will always involve representation. Realists who have a similar view of freedom as effective power to the one I have identified in Sen and Cabral tend to focus on concrete forms of domination and how best to overcome them collectively via representatives. Sen does not think about democratic participation and resistance in these terms. His view is informed by a more idealistic faith in the role of public reason and social choice. 'Indeed, the basic connection between public reasoning, on the one hand, and the demands of participatory social decisions, on the other, is central not just to the practical challenge of making democracy more effective, but also to the conceptual problem of basing an adequately articulated idea of social justice on the demands of social choice and fairness' (2009: 112-113). 
In concrete terms, this brings us back to two associated perennial divisions in political theory and development studies. First, if your view of politics and conceptual language is focussed on reasoned deliberation and impartial mechanisms and institutions for carrying out these processes, it is easy to put a great deal of faith in collaborative and consensual global institutions such as the UN; by contrast, realists tend to be more sceptical of these kinds of approaches. Second, the first kind of position tends also to assume that a gradualist approach to political change is preferable. Radical realists, on the other hand, argue that real change is only possible if the existing authorities, representatives or winners in the status quo are faced with a binary choice - the threat of revolution or structural change.

As regards this second perennial division, the recent examples of struggles to overcome our climate crisis, the legacies of colonial oppression and racism are apt. Progressive gradualists, as they might be labelled, assume (or hope) that enough scientific and rhetorical pressure on national and international representatives (especially law-makers) will translate - over time and due to the 'facts of the matter' - into policy change that would enable us to avert the existential crises and instances of stark injustice. Realist theorists and activists, such as \#ExtinctionRebellion, \#RhodesMustFall and \#BlackLivesMatter, view the powerful institutional matrices as constellations of power that have too much to lose to affect change under such civil disagreement and pressure. They identify that under extant conditions of power and its potential loss, impartial arguments based on justice and injustice will change little. They have reached a point where they realise that a true choice must be forced on the matter. In order to do so, they must take to the streets to make it clear that the people will not allow their representatives to deliberatively sustain colonial oppression or racism or justly lead them to possible extinction. The reason for their success in generating a responsive audience is because, although politics is not always a zero-sum game, they realise that the best way of generating change is to make it seem like a zero-sum game. Most structural change and a substantial proportion of significant policy shifts depend ultimately on resistance by one group or another, resistance that is most effectual if it makes maintaining the status quo a lot harder than changing the status quo. ${ }^{10}$ 
As the \#RhodesMustFall and \#BlackLivesMatter movements bring out well, this binary, confrontational approach to political change must be ready for the possibility of conflict; and however challenging facing these dangers may be in the moment, it will be worth it in the end. Uncivil resistance to the status quo may be more perilous than civil disobedience, but it is also much more effectual; the agents of change are normally ordinary people, even if it is their representatives who may go about actually changing the law. As Mandela and Cabral have taught us, depending on circumstance, this resistance may be non-violent or violent, but it cannot hope to change things unless it is unequivocal about the fact that, in order to change the law, agents of change may have to break the law (cf. Scheuerman 2015).

Sen's view of justice and democracy, by contrast, does not condone these kinds of practices to bring about political change. This is in part due to the fact that one of the concomitant effects of excluding artificially the centrality of potential conflict in politics is that uncivil resistance is ruled out of court. This is the case despite what Sen says about the importance of plural interests, concerns, values and judgements. Given the inherent partiality of and conflict over interests in every form of politics, ruling uncivil resistance out of court is highly problematic for democratic politics. The priority that Sen gives to impartiality and public reasoning is in danger of having the effect of brushing under the carpet the main matters of dispute in any particular time and place. Rather, the answers may lie in a view of a politics that directly confronts and incorporates this conflict by means of partisan institutions that would enable citizens to participate more actively in the determination of their needs. And, however counterintuitively, this may require an institutional configuration that gives their political representatives greater autonomy in the identification and evaluation of needs and interests, while providing citizens with the means meaningfully to control, critique and veto the decisions of these representatives (Dunn 2014; Geuss 2008a; Hamilton 2014b; McCormick 2011; Vergara 2020).

\section{Conclusion}

By comparing how Cabral and Sen navigate their ethics and politics, in this article a form of radical realism in political theory and 
development studies is brought out. This radical realism is not normatively neutral. It is aimed at specified - often seemingly impossible - prized outcomes. It depends on resistance sustained by the goal of freedom as effective power at various levels and in numerous forms. Cabral and Sen may begin from similar places as regards development and freedom, and they may share common values and aim to transgress and critique existing shibboleths, but their politics diverges radically, especially as regards resistance, domination and conflict. A comparative approach is most helpful in seeing this, especially if the comparison pivots around the importance of political change directed towards empowerment to overcome domination and with the goal of inclusive development. It needs to be overtly partial: it must take sides in order to achieve specific goals in real-world contexts to the advantage and power of the previously excluded.

It follows, therefore, that in order to be more realist Sen's work on capability, freedom, justice and democracy would need to be articulated in a different mode. This mode would have to be more diagnostic and synoptic in character, providing citizens across the spectrum with the means to criticise existing economic and political institutions and practices. It would need to provide citizens with the real means, power or capabilities to (1) overcome obstacles in their everyday lives; (2) resist social convention; (3) choose their representatives; and (4), by means of their representatives, influence their social and economic environment. Although Sen provides us with the substantive ingredients for a distinct conceptual schema to the one that still predominates in our highly unequal and impoverished world, (mostly) he ignores institutions and power relations. Thus, Sen's ground-breaking theoretical innovations fail to guide political judgement in the real world of politics. We are left with what we would marshal in a deliberative exercise aimed at decreasing deprivations.

Action-guiding radical realists, such as Cabral, by contrast, focus relentlessly on understanding local conditions, concerns, power relations, values and forms of resistance while resisting foreclosure and inviting imaginative local and global forays into what for so many millions seemed like an impossible dream for so long: freedom from colonial oppression and domination. In sum, the realist focus on freedom, resistance and change does not determine our 
view of what is possible. But it can reveal how liberating practical contexts and challenges (and comparisons thereof) can be for our imaginative forays into how we can be and live better together.

\section{Acknowledgements}

I am indebted to the South African National Research Foundation, the Newton Fund and the British Academy for their financial support, which comes in the form of the SA-UK Bilateral Research Chair in Political Theory that I hold and they fund (grant number 103137). I am grateful to audiences in Accra, Bath, Brighton, Cambridge, Johannesburg, London and Norwich for comments on earlier presented versions of this article. I am indebted to two anonymous reviewers for Theoria and numerous colleagues and friends who have read and commented on this article. I have not been able properly to respond to all suggestions and criticisms, but all have made me think harder and helped improve this piece. The usual disclaimer applies.

Lawrence Hamilton is the SA-UK Bilateral Research Professor in Political Theory, Witwatersrand and Cambridge. He contributes to rethinking political theory and development from and for the Global South. He has held visiting positions in Salvador, Caracas, Cape Town and Cambridge, and is an elected member of the Academy of Science of South Africa. His many articles and books include Amartya Sen (Polity, 2019), Freedom Is Power: Liberty through Political Representation (Cambridge University Press, 2014), Are South Africans Free? (Bloomsbury, 2014) and The Political Philosophy of Needs (Cambridge University Press, 2003). He co-directs the Association of Political Theory in Africa (APTA) and directs the Universities of Witwatersrand and Cambridge (WITS-POLIS) Exchange Programme. He holds a National Research Foundation (NRF) A-rating. E-mail: lawrence.hamilton@wits.ac.za

\section{Notes}

1. A note on Cabral references in this article: with the exception of this recently republished work, I do not provide the original date of delivery or publication of 
all the different works and speeches that make up the volumes cited here, for this would have led to an overly complex date and title identification process, due to the sheer number of speeches and articles used; rather, I reference the first English language publication and leave the interested reader to identify the exact source via the page references.

2. They were born within ten years of one another, and they came to global presence in the 1960s and 1970s. And who is to say that Cabral would not have gone on to be a world-famous thinker had he not been assassinated on 20 January 1973, at the age of 48, by members of a disaffected group of the PAIGC with the aid of the Portuguese secret police (PIDE)?

3. For more on 'public action' and its relation to development, especially in India, see Drèze and Sen (2013).

4. There was then a second, if highly stylised, move: given the facts of humans now, how we can use these ideal blueprints to criticise existing institutions and practices (Cohen 2003). But I lay this to one side for the purposes of this article.

5. Sen's emphasis on freedom of choice as regards functionings is obvious: 'The freedom to choose between alternative functioning bundles reflects a person's "advantage" - his or her capability to function. ... [and] [o]ne reason why freedom may be important is that "choosing" may itself be an important functioning' (1988: 279, 290).

6. Cabral reiterates the significance of Portugal's underdevelopment both for Portuguese citizens and colonial subjects in several other places (e.g. Cabral 1969; 1972).

7. He was even more forthright about the idea of a 'return to the source'. He argued that it arose 'mainly from the assumption that all Black Africans have a cultural identity', as espoused by native elites in decolonising African countries and by Pan-Africanism or Negritude, with its origins outside Africa; that is, it was developed by groups alienated from the masses of colonised Africans. It therefore is not and cannot in itself be an act of struggle against foreign domination'. It is the denial of the pretended supremacy of the dominant power. And it can only be part of the struggle if it connects properly to the masses and contests not just the foreign culture but also the foreign domination as a whole (Cabral 1973: 62-63).

8. For an extensive critique of the associated justificatory legal carapace that liberal democracy has created, see Vergara (2020).

9. For the arguments that underpin these points, see Hamilton (2003, 2014b).

10. Another example is provided by Kate Precious (2018). Drawing from recent cases of pro-disability policy change in the United Kingdom, she shows that, even when couched in Sen's language of capability deprivation, significant policy shifts that have enhanced the agency of the disabled only came about as a result of real resistance to existing policy.

\section{References}

Aristotle. 1980. The Nicomachean Ethics. Ed. D. Ross. Oxford: Oxford University Press.

Borges, S. 2019. Militant Education, Liberation Struggle, Consciousness: The PAIGC Education in Guinea Bissau 1963-1978. Berlin: Peter Lang.

Cabral, A. (1969) 2016. 'Analysis of a Few Types of Resistance'. In R. Rebaka and D. Wood (eds), Resistance and Decolonization. London: Rowman and Littlefield, 75-156. 
Cabral, A. 1969. Revolution in Guinea: An African People's Struggle. Ed. R.Handyside. Redhill, UK: Love \& Malcomson.

Cabral, A. 1972. Our People Are Our Mountains: Amilcar Cabral on the Guinean Revolution. Ed. B. Davidson. London: Committee for Freedom in Mozambique, Angola and Guiné.

Cabral, A. 1973. Return to the Source: Selected Speeches of Amilcar Cabral. New York: Monthly Review Press.

Cabral, A. 1979. Unity and Struggle: Speeches and Writings of Amílcar Cabral. Ed. B. Davidson. New York: Monthly Review Press.

Cohen, G. 2003. 'Facts and Principles'. Philosophy \& Public Affairs 31 (3): 211-245. https://www.jstor.org/stable/3558005.

Drèze, J. and A. Sen. (2013) 2020. An Uncertain Glory: India and Its Contradictions. London: Penguin.

Dunn, J. 2014. Breaking Democracy's Spell. New Haven, CT: Yale University Press.

Fanon, F. (1961) 2001. The Wretched of the Earth. London: Penguin.

Geuss, R. 2001. History and Illusion in Politics. Cambridge: Cambridge University Press.

Geuss, R. 2008a. Philosophy and Real Politics. Princeton, NJ: Princeton University Press.

Geuss, R. 2008b. 'Philosophical Anthropology and Social Criticism'. In A. Honneth (ed.), Reification: A New Look at an Old Idea. Oxford: Oxford University Press, 120-131.

Geuss, R. 2014. 'Politics and Architecture'. In A World without Why. Princeton, NJ: Princeton University Press, 144-162.

Geuss, R. 2016. 'Realism and the Relativity of Judgement'. In Reality and Its Dreams. Cambridge, MA: Harvard University Press, 25-50.

Hamilton, L. 2003. The Political Philosophy of Needs. Cambridge: Cambridge University Press.

Hamilton, L. 2013. 'Real Modern Freedom'. Theoria: A Journal of Social and Political Theory 60 (4): 1-28, doi:10.3167/th.2013.6013701.

Hamilton, L. 2014a. Are South Africans Free? London. Bloomsbury.

Hamilton, L. 2014b. Freedom Is Power: Liberty Through Political Representation. Cambridge: Cambridge University Press.

Hamilton, L. 2019. Amartya Sen. Cambridge: Polity.

Hampshire, S. 2000. Justice Is Conflict. Princeton, NJ: Princeton University Press.

Hountondji, P. 1997. African Philosophy: Myth and Reality. Bloomington: Indiana University Press.

Marx, K. (1867) 1976-1978. Capital. Harmondsworth, UK: Penguin.

Marx, K. (1939-1941) 1973. Grundrisse. Harmondsworth, UK: Penguin.

McCormick, J. P. 2011. Machiavellian Democracy. Cambridge: Cambridge University Press.

Precious, K. 2018. 'Autism on the Agenda: An Analysis of the Campaign behind the Autism Act 2009'. MA diss., University of Bath. 
Prinz, J. 2016. 'Raymond Geuss' Radicalization of Realism in Political Theory'. Philosophy and Social Criticism 42 (8): 777-796. doi:10.1177/0191453715583711.

Raekstad, P. 2015. 'Two Contemporary Approaches to Political Theory'. International Critical Thought 5 (2): 226-240. doi:10.1080/21598282.2015. 1032322.

Rossi, E. and M. Sleat. 2014. 'Realism in Normative Political Theory'. Philosophy Compass 9 (10): 689-701. doi:10.1111/phc3.12148.

Runciman, D. 2012. 'What Is Realistic Political Philosophy'. Metaphilosophy 43 (1-2): 58-70. doi:10.1111/j.1467-9973.2011.01730.x.

Sankara, T. 2007. 'Dare to Invent the Future'. In M. Prairie (ed.), Thomas Sankara Speaks. London: Pathfinder Press.

Scheuerman, W. 2015. 'Recent Theories of Civil Disobedience: An AntiLegal Turn'. Journal of Political Philosophy 23 (4): 427-449. doi:10.1111/ jopp. 12055 .

Sen, A. 1973. On Economic Inequality. Oxford: Oxford University Press.

Sen, A. 1980. 'Equality of What?'. In S. McMurrin (ed.), The Tanner Lectures on Human Values, Vol. 1. Cambridge: Cambridge University Press, 195-220.

Sen, A. 1981. Poverty and Famines. Oxford: Clarendon Press.

Sen. A. 1983. 'Development: Which Way Now?' The Economic Journal 93 (372): 745-762. doi:10.2307/2232744.

Sen. A. 1985. 'Well-Being, Agency and Freedom: The Dewey Lectures 1984'. Journal of Philosophy 82 (4): 169-221. doi:10.2307/2026184.

Sen, A. 1987. On Ethics and Economics. Oxford: Blackwell.

Sen. A. 1988. 'Freedom of Choice: Concept and Content', European Economic Review 32.

Sen, A. 1993. 'Capability and Well-Being'. In M. Nussbaum and Sen (eds), The Quality of Life. Oxford: Clarendon Press, 30-53.

Sen, A. 1999. Development as Freedom. New York: Knopf.

Sen, A. 2006. 'What Do We Want from a Theory of Justice?' The Journal of Philosophy 103 (5): 215-238. https://www.jstor.org/stable/20619936.

Sen, A. 2009. The Idea of Justice. London: Allen Lane.

Sen. A. 2014. 'Amartya Sen on Elections, Communal Politics and Inequality in India'. Mondiaal Nieuws, 8 April. http://www.mo.be/en/interview/amartyasen-elections-communal-politics-and-inequality-india.

Sen, A. 2015. The Country of First Boys. New Delhi: Oxford University Press. Shapiro, I. 2011. 'Review of Sen's The Idea of Justice'. Journal of Economic Literature 49 (4): 1251-1263. https://www.jstor.org/stable/23071672.

Shapiro, I. 2016. Politics against Domination. Cambridge, MA: Harvard University Press.

Shubin, V. 2017. 'Moscow and Zimbabwe's Liberation'. Journal of Southern African Studies 43 (1): 225-233. doi:10.1080/03057070.2017.1275108.

Smith, A. (1790) 1976. The Theory of Moral Sentiments. Ed. D. D. Raphael and A. A. Mackie. Oxford: Clarendon Press. 
Tully, J. 2013. 'Two Ways of Realizing Justice and Democracy: Linking Amartya Sen and Elinor Ostrom'. Critical Review of International Social and Political Philosophy 16 (2): 220-232. doi:10.1080/13698230.2012.757914.

Vergara, C. 2020. Systemic Corruption: Constitutional Ideas for an AntiOligarchic Republic. Princeton, NJ: Princeton University Press.

Williams, B. 2005. In the Beginning Was the Deed. Princeton, NJ: Princeton University Press. 